\title{
CORRESPONDENCE
}

\section{ENTROPION OF UPPER EYELID COMPLICATING TRACHOMA}

\section{To the Editorial Committee of the British Journal of OPHTHALMology}

SIRS,--Since the publication of my article "Early changes in margin of upper eyelid in entropion complicating trachoma" in the October issue of the Journal (Brit. J. Ophthal., 1965, 49, 538), my attention has been drawn to an article by Prof. A. Kettesy. This publication "On genesis and operation of the cicatricial (trachomatous) entropion of the upper lid" appeared in the British Journal of Ophthalmology in July, 1948 (Brit. J. Ophthal., 1948, 32, 419), and I regret that I had overlooked it in my search through the literature.

It is evident that the phenomenon of traction on the lid margin, on which I based my suggested classification of trachomatous entropion, was described by Prof. Kettesy in 1948 and was used by him in designing his well-known operation for the relief of entropion, an operation which now bears his name.

May I now make acknowledgement, through your columns, of Prof. Kettesy's work. I should certainly have done this in my article had I not overlooked his publication, an oversight which I sincerely regret.

JaNe Furse Memorial Hospital, Yours faithfully, John W. R. Sarkies. via Middelburg,

TransVaAL, South AFrica.

December 23, 1965.

\section{OBITUARY}

\section{SIR GORDON MORGAN HOLMES (1876-1965)}

Sir Gordon Holmes was not an ophthalmologist, but he was known to our readers all over the world, who will regret his death on December 29, 1965, at the age of 89 years. An Irishman who qualified in medicine in Dublin, he started research in neurology with Ludwig Edinger of Frankfurt, and throughout a full and busy life maintained that habit with a brilliance that has greatly enriched both neurology and ophthalmology. His professional life was spent primarily at the National Hospital for Nervous Diseases, Queen Square, London, but he was on the medical staff of Moorfields Eye Hospital and was Secretary of the Ophthalmological Society (1912-15) and later its President (1936-8).

During the years between the two world wars he was one of the greatest clinicians and teachers in the English-speaking world. He may be said to have been the last of the great succession of neurologists at the National Hospital who, starting from Jackson and Ferrier, established English neurology, and ten of whom, including Holmes, became Fellows of the Royal Society. His research work, undertaken (as was most at that time) on his own resources and without financial support, included much of ophthalmological interest, particularly the effects of injuries to the visual pathways as observed during the First World War, and the role of the cerebral cortex in visual sensations. It is good that he lived to a ripe old age to see himself fully honoured and to witness the successes gained by the hundreds of pupils in neurology and ophthalmology whom his clinical teaching and example inspired. 